\title{
Cyclones, Tsunamis, and Human Health The Key Role of Preparedness
}

Besides the many benefits of the ocean, human and other populations living in coastal regions share in the risk for meteorological and seismic hazards that originate from the seas. Tropical cyclones (also known as typhoons and hurricanes) and tsunamis represent the most powerful and destructive of all marine hazards.

Tropical cyclones have caused an estimated 1.9 million deaths worldwide during the past two centuries (Nicholls et al., 1995). During 1980-2000, an average of 11,800 deaths per year were attributed to cyclones (United Nations Development Programme, 2004). The three deadliest cyclones produced catastrophic loss of life: 300,000 deaths and 138,000 deaths in the Bangladesh cyclones of 1970 and 1991, respectively, and 100,000 deaths in the Chinese typhoon of 1922. Sixteen of the 18 deadliest tropical cyclones occurred in the Asia-Pacific region.

Tsunamis have the potential to cause an enormous impact upon the health of millions. Since 1945, more people have been killed by tsunamis than by earthquakes (Noji, 1997; McCarty, 2002). In a 100-year period from 1895 to 1995, there were 454 tsunamis recorded in the Pacific, the deadliest 94 killed over 51,000 people (Boyarsky and Shneiderman, 2002). The 2004 Indian Ocean tsunami killed nearly 300,000 and affected over 2,000,000 two million people in twelve nations. (U.S. Geological Survey, 2005).

The human-health effects of cyclones and tsunamis cannot be understated. In addition to the public health and medical consequences of these disasters, the social, cultural, and psychological impact of cyclones and tsunamis have an enormous and long-lasting impact throughout the world, and a direct effect upon human development in general (see Miller case study, this issue). Table 1 compares the public-health impact of cyclone and tsunami disasters.

Drowning during the impact phase of the disaster causes the overwhelming majority of deaths from cyclones and tsunamis. Populations are at risk of death simply by virtue of their physical proximity to low-lying land situated near the coastline. However, there is significant promise for the future in that nearly all these deaths are preventable with the proper advance warning and population evacuation. Very few drowning victims would be expected to survive the initial inundation, even with the added benefit of fully adequate emergency-response capacity. Preparedness is the key to preserving human life in the setting of cyclones and tsunami disasters. All other measures are less effective, less compassionate, and much more expensive.

Whenever there is a disruption of routine public health services (like that which occurs after a cyclone or tsunami), there is the potential for secondary adverse health effects to develop among the disaster-affected population. The best opportunity to prevent or lessen secondary health effects is during the emergency-response phase. 


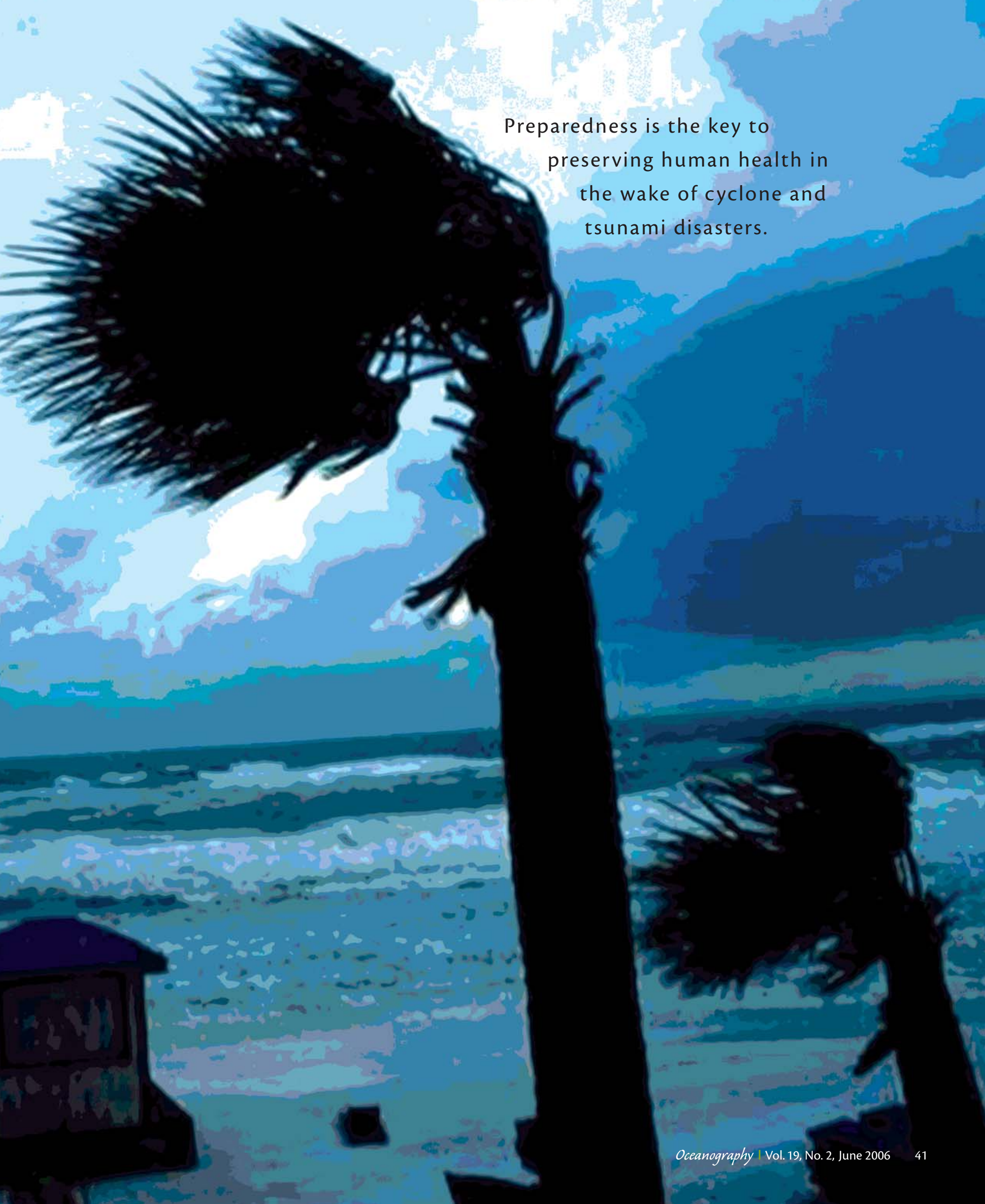




\section{TROPICAL CYCLONES}

\section{(AKA TYPHOONS AND \\ HURRICANES)}

\section{Background}

Tropical cyclones are low-pressure weather systems that develop over the warm waters of the oceans, typically between the latitudes of $30^{\circ} \mathrm{N}$ and $30^{\circ} \mathrm{S}$ (Malilay, 1997; Williams, 1997). Cyclonic storms with wind speeds surpassing $74 \mathrm{mph}$ (118 kph) are termed tropical cyclones. Depending upon geographic location, tropical cyclones are referred to as "hurricanes" in the North Atlantic, the Caribbean, the Gulf of Mexico, the eastern North Pacific, and the west coast of Mexico; "typhoons" in the western Pacific; and "cyclones" in the Indian Ocean and Australasia (Malilay, 1997).
Because warm ocean water is necessary to power cyclone formation, only the planet's midsection can conceive tropical cyclones. Wind circulation within a cyclone is controlled by an approximate balance between pressure gradient and Coriolis forces; the bigger the pressure differential, the faster the winds. Because the direction of the Coriolis force with respect to wind velocity is opposite in the northern and southern hemisphere, cyclones rotate in a counterclockwise direction in the northern hemisphere and a clockwise direction in the southern hemisphere. A corollary is that cyclones can neither form at nor cross the equator. Consequently, tropical cyclones are constrained to form within two tropical belts: one above the equator (where two-thirds of storms develop), and one below the equator (Schultz, 2005).

\section{Human-Health Impact of Cyclones Mortality Trends}

Prior to the implementation of earlywarning, evacuation, and shelter systems, drowning from storm surge accounted

Mark E. Keim, M.D. (mkeim@cdc.gov) is Medical Officer and Team Leader, International Emergency and Refugee Health Branch, National Center of Environmental Health, US Centers for Disease Control and Prevention, Atlanta, GA, USA and Clinical Associate Professor, Department of International Health and Development, Tulane University School of Public Health and Tropical Medicine, New Orleans, LA, USA.

Table 1. Public Health Consequences of Cyclones and Tsunamis

\begin{tabular}{|l|l|l|}
\hline Consequence & Cyclones & Tsunami \\
\hline Death rates & $\begin{array}{l}\text { Developed nations - Low } \\
\text { Developing nations - High }\end{array}$ & High \\
\hline Severe injuries (\% among survivors) & Few & Few to moderate \\
\hline Loss of clean water & Widespread & Focal to widespread \\
\hline Loss of shelter & Widespread & Focal to widespread \\
\hline Loss of personal and household goods & Widespread & Focal to widespread \\
\hline Major population movements & Rare & Rare \\
\hline Loss of routine hygiene & Widespread & Focal to widespread \\
\hline Loss of sanitation & Widespread & Focal to widespread \\
\hline Disruption of solid waste mgt & Widespread & Focal to widespread \\
\hline Public concern for safety & High & High \\
\hline Increased pests and vectors & Widespread & Focal to widespread \\
\hline Loss and/or damage of health care system & Widespread & Focal to widespread \\
\hline Worsening of existing chronic illnesses & Widespread & Focal to widespread \\
\hline Loss of electricity & Widespread & Focal to widespread \\
\hline Toxic exposures & Possible & Possible \\
\hline Food scarcity & Common in low-lying remote islands & Common in early stages only \\
\hline
\end{tabular}


for an estimated 90 percent of cycloneattributable mortality in both developed and developing nations (Malilay, 1997).

Storm-surge drowning deaths have decreased markedly in developed nations due to improvements in hurricane forecasting, evacuation, and shelter procedures (Centers for Disease Control and Prevention [CDC], 1989b). Now, most of the storm-related mortality, and much of the morbidity, occurs during the postimpact period; however, if major infrastructure damage is sustained, it can be difficult to document the true extent of mortality and morbidity. In developed nations, the most prominent causes of death and injury are electrocutions from downed power lines, chain-saw injuries, blunt trauma from falling trees, and motor-vehicle fatalities occurring during the early post-impact period (CDC, 1989a; Philen, 1992). Unfortunately, storm surge remains the primary cause of mortality following tropical cyclones in developing nations that lack critical preparedness measures (Chowdury et al., 1992; Diacon, 1992).

\section{Storm-Associated IIIness}

\section{and Injury}

Injury represents the major cause of death and the primary cause of morbidity for tropical cyclones (Meredith, 2002). The top three cyclone-related injuries are lacerations, blunt trauma, and puncture wounds, with 80 percent of these injuries being confined to the feet and lower extremities (Noji, 1993). An increased incidence of animal and insect bites following tropical cyclones has also been noted (CDC, 1986, 1996, 2000). Chronic diseases (such as asthma and emphysema) are also known to be exacerbated after cyclones and other natural disasters. There is also a potential for exposure to hazardous materials during the impact, as well as during the clean-up phase of the disaster.

\section{Infectious Diseases}

Outbreaks of infectious diseases follow-

ing tropical cyclones are rare (World

Heath Organization [WHO], 1979;
Psychosocial Consequences

Behavioral health effects are among the most long-term and debilitating outcomes of natural disasters, including tropical cyclones (WHO, 1992; Ursano, 1994). Some persons experience persistent distress, post-traumatic stress disorder (PTSD), major depression, or other psychiatric outcomes. An elevated prevalence of PTSD was specifically apparent

\section{The world can no longer afford to sustain these significant losses in human development caused by these types of catastrophic natural disasters.}

Toole, 1997; CDC, 1999, 2000; Guill and Shandera, 2001). In developed nations, post-hurricane infectious disease surveillance has occasionally detected increases in self-limiting gastrointestinal disease and respiratory infections (Lee et al., 1993; CDC, 2000, 2002), but more typically, no increase in communicable disease is found (CDC, 1993; Toole, 1997). There have been a few reports of isolated outbreaks associated with vector-borne illness in developing nations. For example, interruption of health services including an anti-malaria campaign may have contributed to a malaria outbreak in Haiti following Hurricane Flora in 1963 (Mason and Cavalie, 1965; Bissell, 1983). Following Hurricane Mitch in 1998, rates of dengue fever increased in Guatemala and Honduras, and the numbers of malaria cases increased in Guatemala and Nicaragua (Pan American Health Organization [PAHO], 1998). in three studies of hurricane survivors in developing nations (Caldera et al., 2001; Goenjian et al., 2001; Sattler et al., 2002). Rates of suicide (Krug, 1998) and child abuse (Keenan et al., 2004) appear to rise following natural disasters. The National Institute of Mental Health (NIMH) has been quite proactive in seeking to address mental-health issues of those disaster victims affected by Hurricane Katrina (Insel, 2005).

\section{TSUNAMIS}

\section{Background}

The Japanese word tsunami translates in English to "harbor wave." A tsunami is a series of ocean waves generated by any disturbance that displaces a large water mass (Boyarsky and Shneiderman, 2002). About 90-95 percent of tsunamis are caused by large earthquakes (usually magnitude 7.5 or greater) at subduction zones (where one tectonic plate slides 
over another); the remainder are primarily due to volcanic eruptions (like the eruption of Mt. Krakatoa in 1883) or landslides (like the 1998 Papua New Guinea tsunami generated by a submarine landslide). There are also composite events such as the 1946 subduction earthquake in the Aleutian Islands that triggered a landslide-generated tsunami killing 159 in Hawaii (Fryer et al., 2003). Prehistoric geological evidence has implicated meteorites or comet impacts as a rare cause of tsunami (Bolt, 1978).

Earthquakes caused by large, sudden fault movement at subduction zones are most often associated with generation of the largest tsunamis (e.g., the Sumatra earthquake and tsunami of December 2004). The amount of fault slip is an important factor in determining tsunami size. At subduction zones, the fault zone affected may be as much as hundreds of kilometers long. Vertical movement on the fault may displace tens of cubic kilometers of water. The December 2004 tsunami, for example, caused the seabed to uplift (or subside) 6-10 $\mathrm{m}$ in places, displacing an estimated $30 \mathrm{~km}^{3}$ of water (Dalrymple et al., 2006). Depth of fault movement is also an important factor in determining whether a tsunami will be generated; shallower ruptures that break the seafloor will generate larger initial tsunamis. No tsunami was reported for the magnitude 8.7 earthquake that shook Indonesia on March 28, 2005 (leaving 2,000 people feared dead on the island of Nias), likely because fault movement did not break through to the seafloor. In addition, that earthquake occurred beneath shallower water, where less water displacement would occur (Hopkin, 2005; Kerr, 2005).

Once the tsunami is generated, a series

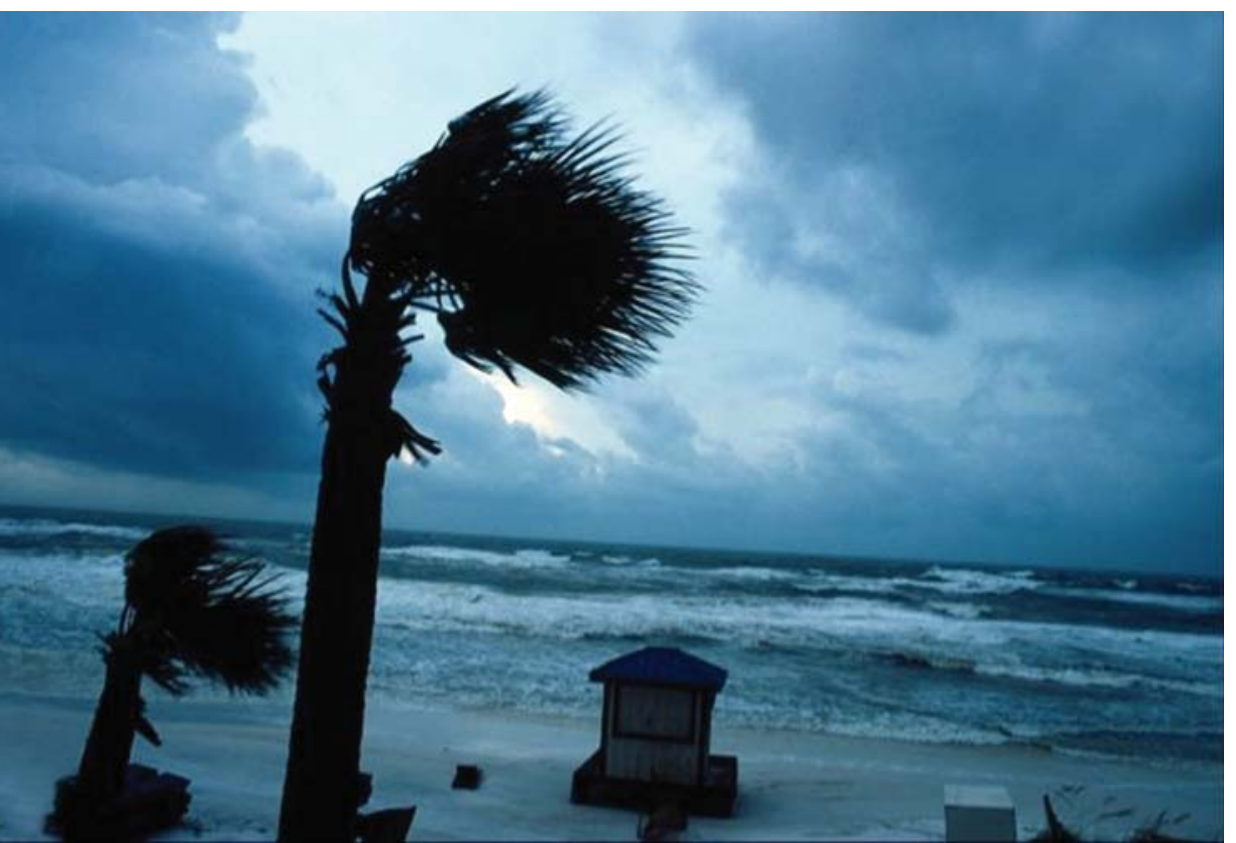

Figure 1: View of the western Pacific Ocean during a cyclone. of extremely low-frequency, long-wavelength $(\sim 300 \mathrm{~km})$ waves propagate in an expanding radius from the area of displacement. These waves differ importantly from surface waves (i.e., those caused by wind) in that tsunami waves are propagated throughout the entire depth of the ocean. For this reason, tsunamis represent a tremendous amount of potential energy, and can travel the speed of a jet airliner (300-600 mph or 500-1000 kph) in deep, open water. Because the energy is spread throughout such a large volume in deep water, tsunamis may be only a few feet high in mid ocean, making them capable of passing under ocean-going ships with little disturbance or detection. The physical characteristics of the fluid pressure wave allow it to travel great distances with very little loss of energy. For example, a subduction earthquake that occurred on January 26, 1700 at the Cascadia subduction zone, encompassing western Washington and Oregon, generated a tsunami that destroyed the island of Honshu (Japan) (Anonymous, 1997; Satake et al., 2003). About 90-95 percent of the world's tsunamis have occurred in the Pacific Ocean due to its relatively large size and its bordering "Ring of Fire" comprised of major subduction zones. Great trans-Pacific tsunamis are typically caused by massive earthquakes located at these subduction zones and occur at an interval of about once a decade (McCarty, 2002) (Figure 1).

As the tsunami enters shallow water near coastlines, the kinetic energy previously spread throughout the large volume of deep ocean water becomes concentrated to a much smaller volume of water, resulting in a tremendous destructive potential as it inundates the land. 
Successive crests may arrive to shore at intervals of every 10-45 minutes. This phenomenon is particularly problematic when responders attempt to rescue victims from the water after the first wave, only to become themselves victimized by subsequent waves. A single tsunami may be comprised of up to twelve wave crests. Prior to inundation of the wave crest, the sea may recede for an unusually long distance. During the 1960 Chilean tsunami that struck Hilo (Hawaii), this phenomenon tended to attract more people to the shoreline and into the ocean itself, where they were then caught up in the oncoming wave crest. One village in Papua New Guinea reportedly recognized this as a sign of an impending tsunami and took protective actions for shoreline evacuation. In Simelue (Indonesia), an old song about moving to high ground when the earth shakes is reported to have saved lives, and resulted in a relatively low death rate compared to neighboring Sumatra (which was further from the quake epicenter).

A tsunami is usually 3-15 $\mathrm{m}$ high. Wave heights averaged $24 \mathrm{~m}$ above sea level along the western coastline of $\mathrm{Su}$ matra during inundation of the 2004 Indian Ocean tsunami earthquake (Paulson, 2005). A 70-m wave was recorded following the 1964 Alaska earthquake (Alaska Division of Emergency Services, 1992). Extremely rare mega-tsunamis produced by giant submarine landslides have been implicated globally (McMurty et al., 2004). Evidence of soil stripping and coral deposits purportedly caused by tsunami inundation has been reported up to an elevation of $365 \mathrm{~m}$ in Hawaii (McMurty, 2004). At least 100 mega-tsunamis in different parts of

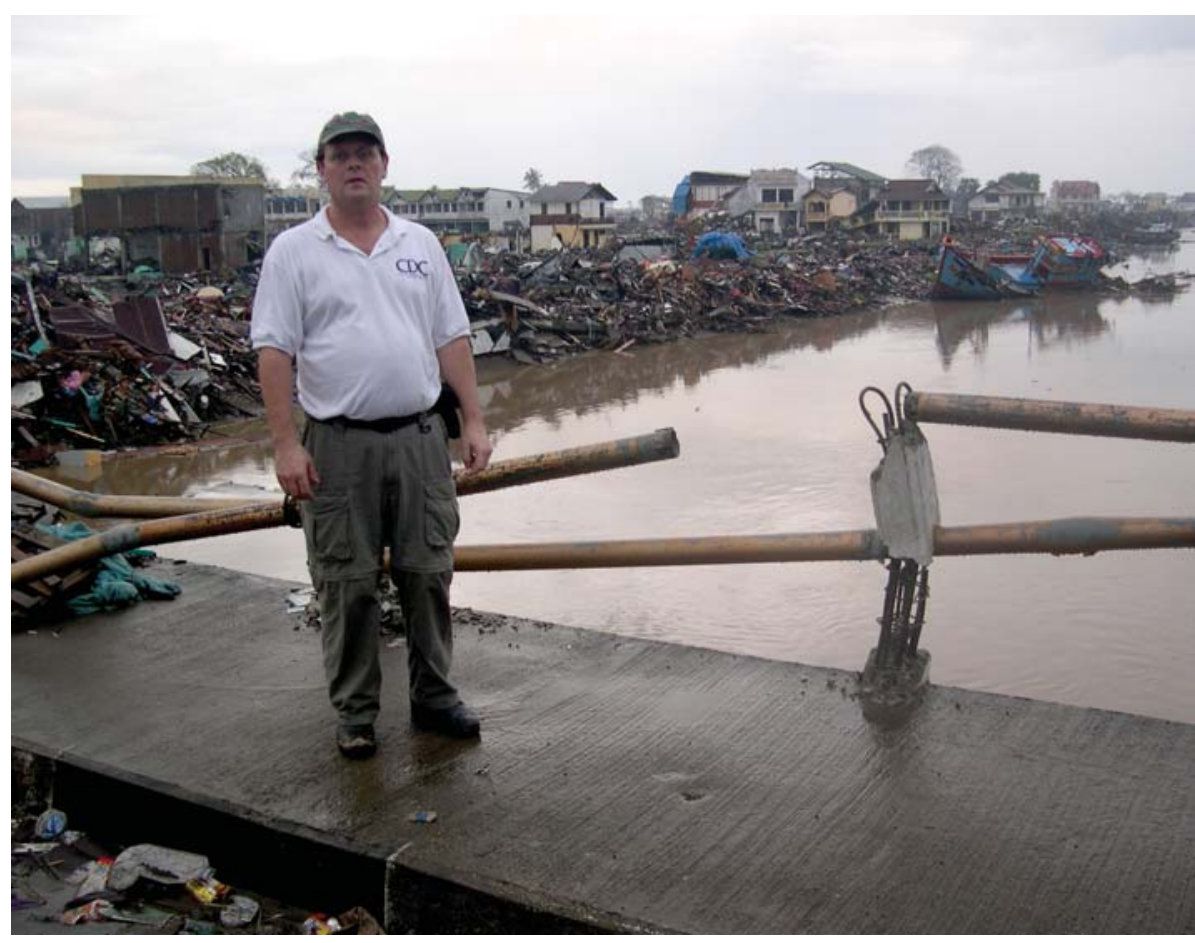

Figure 2. Author surveying tsunami damage in Banda Aceh, Indonesia.

the world have been recorded in the past 2000 years according to interpretation of the sedimentologic and geomorphic imprints left by these events (Scheffers and Kelletat, 2003). The highest tsunami wave ever witnessed occurred at Lituya Bay (Alaska) in 1950. It was triggered by a magnitude 8.0 earthquake-induced landslide, and reached the height of $524 \mathrm{~m}$ above the shoreline (i.e., a height three stories higher than the World Trade Center of New York City) (Boyarsky and Shneiderman, 2002).

\section{Human-Health Impact of Tsunamis Mortality Trends}

The vast majority of tsunami-related deaths occur immediately (McCarty, 2002). In a large tsunami, deaths frequently exceed the number of injured.
Average death rates are believed to be 50 percent for the population caught up in a tsunami (McCarty, 2002). The 30,000 inhabitants of Calang in Aceh province (Indonesia) suffered an estimated 70 percent mortality rate during inundation of the December 26, 2004 tsunami (Brennan and Rimba, 2005). Most deaths resulted from drowning.

However, a tsunami does not consist only of water. It also contains a great amount of debris traveling with tremendous momentum. The same 2004 Indian Ocean tsunami is estimated to have been traveling at $30 \mathrm{mph}(48 \mathrm{kph})$ when on shore in Aceh province (Indonesia). Figure 2 reveals extensive destruction and debris left in the wake of the tsuna$\mathrm{mi}$ in the city of Aceh (Indonesia).

According to a survey recently car- 
ried out by Oxfam (2005), four times as many women as men were killed in the tsunami-affected areas of Indonesia, Sri Lanka, and India. Some of the reasons postulated for this are similar across these countries: women died because burial ceremonies due to the misconception that the dead bodies themselves pose a health threat (Guha-Sapir and van Panhuis, 2005). It is well established, however, that dead bodies do not pose a health threat, and it is more important

\section{...it is possible to detect tsunamis and}

cyclones in advance of these hazards, and provide early warning before they

strike those vulnerable populations living along coastlines in their paths.

they stayed behind to look for their children and other relatives. Women in these areas often cannot swim or climb trees, which meant that they could not escape.

Deaths from tsunami injuries occur in three phases. Victims usually succumb to injuries that are incompatible with life (severe head, chest, and spine injuries) within the first few minutes. Then immediate complications set in over the next few minutes to hours (such as bleeding, lung collapse, and blood clots in the lung). Finally, these immediate causes of death are followed by delayed complications over the coming days that are mostly associated with infectious disease (such as wound infections and aspiration pneumonia) (Kongsaengdao, 2005).

The large number of dead bodies became an issue of public concern in the wake of the 2004 Indian Ocean tsunami. Many families were not allowed to recover their dead or to observe traditional for families to recover their dead for psychological reasons than to bury them for sanitary purposes (Morgan, 2004).

\section{Tsunami-Associated IIIness and Injury}

A tsunami directly injures the victims by the mechanism of blunt trauma and penetrating injury (Taylor et al., 1998). People are bludgeoned by concrete slabs and felled trees, stabbed by jagged sheets of metal and glass, tangled up in manacles of wire, and impaled onto tree limbs and bamboo. Soil, small pieces of wood, glass, and metal in the contaminated saltwater penetrate the soft tissues of the body at high velocity.

When the 2004 Indian Ocean tsunami hit the western coast of southern Thailand, six to eight huge waves measuring 5 to 7 meters high destroyed almost everything along the beach and inundated areas more than 300 meters from the seashore. Most of the survivors had minimal to moderate injuries to the body and extremities. Causes of death included drowning, entrapment inside collapsing buildings, and being thrown under cars (Lim, 2005). No survivor of the Papua New Guinea tsunami was found to have head, spine, thorax, or abdomen injuries, implying that survival of these life-threatening injuries was virtually impossible in that remote setting with delayed resuscitative and surgical care (Taylor et al., 1998). Bone fractures, soft-tissue injuries, and near-drowning were the most common conditions reported among survivors in Papua New Guinea and of the Indian Ocean tsunamis (Holian and Keith, 1998; Lim, 2005; Watcharong et al., 2005).

As mentioned before, chronic diseases (such as asthma and emphysema) are also known to be exacerbated after natural disasters. And similar to cyclones, tsunamis have the potential to cause exposure to hazardous materials during both the impact as well as the clean-up phases of the disaster. After the 2004 Indian Ocean tsunami, documents written about the tsunami were critical of the over-abundance of health resources focused on non-emergent trauma care as compared to relative lack of attention paid to the needs of special populations, including the elderly (Mudur, 2005) and maternal-child and women's health (Brennan and Rimba, 2005; Mudur, 2005; Perera, 2005).

\section{Infectious Diseases}

Near-drowning is common in tsunamis and is frequently associated with aspiration pneumonia or "tsunami lung" (Holian and Keith, 1998; Allworth, 2005; Chierakul et al., 2005). Wounds are in- 
evitably contaminated with soil, debris, and foreign bodies. Therefore, wound infections are common. For example, 16.9 percent of all diagnoses by January 10, 2005 at the International Committee of the Red Cross (ICRC) field hospital in Calang (Indonesia) (Brennan and Rimba, 2005) and 15 percent of all consultations at the ICRC field hospital in Banda Aceh (Indonesia) were for wound infections (Guha-Sapir and van Panhuis, 2005).

Wound infections frequently involve multiple, relatively uncommon pathogens (Lim et al., 2005; Andresen et al., 2005). As was the case in populations affected by hurricanes Andrew and Iniki, tetanus cases increased after the 2004 Indian Ocean tsunami as a result of injuries sustained at the time of impact. The number of cases then returned to baseline within one month of the event (Guha-Sapir and van Panhuis, 2005).

Contrary to initial concerns for outbreaks of malaria, cholera, and dengue (Moszynski, 2005; Krishnamoorthy et al., 2005), the Indian Ocean tsunami, like previous natural disasters, was not associated with epidemics of infectious disease (Guha-Sapir and van Panhuis, 2005). No increases in cases for cholera, measles, malaria, or dengue were noted in Aceh in the post-tsunami period (Guha-Sapir and van Panhuis, 2005). Experience has shown that these diseases, despite common beliefs, are not always a priority immediately after a natural disaster. Overall, the number of disaster-related health conditions needing emergency response decreased substantially within two weeks of the event, and became negligible within four weeks (Guha-Sapir and van Panhuis, 2005).

\section{Psychosocial Consequences}

As mentioned before, behavioral health effects are among the most long-term and debilitating outcomes of natural disasters, including tsunamis (WHO, 1992; Norris, 2005). The monumental devastation of the December 2004 Indian Ocean tsunami prompted a meta-analysis of the psychosocial consequences of natural disasters in developing countries versus developed countries (Norris, 2005). Generally, during a natural disaster, a much higher proportion of the population in developing nations sustains severe loss and extreme trauma, and experiences that constitute clinically significant distress (Schultz et al., 2005). Table 2 compares the direct health effects of cyclones and tsunamis.

\section{THE CRITICAL ROLE OF PREPAREDNESS}

No man-made structure can be relied upon to resist the incredible power of a large tsunami. Seawalls and reinforced construction are of limited benefit (McCarty, 2002). The recent events of Hurricane Katrina in the United States reveal that even well-developed engineering controls can fail in the event of a direct hit by a severe tropical cyclone. In the absence of emergency-preparedness measures, the majority of tsunami- and cyclone-related deaths will occur immediately during the impact phase when emergency response activities are the most vulnerable and the least capable.

As previously noted, since 1945 more people have been killed by tsunamis than

Table 2. Estimated Relative Frequency of Health Effects Associated with Cyclones and Tsunamis

\begin{tabular}{|l|c|c|}
\hline Type of morbidity & Cyclone & Tsunami \\
\hline Crush injury & ++ & ++ \\
\hline Head injury & + & ++ \\
\hline Asphyxiation & + & ++ \\
\hline Isolated bone injury & + & ++ \\
\hline Skin soft tissue injury & + & ++ \\
\hline Burns & + & 0 \\
\hline Drowning & ++ & ++ \\
\hline Asthma/emphysema & + & 0 \\
\hline Hypothermia & 0 & + \\
\hline Epidemics & 0 & 0 \\
\hline Starvation & + & 0 \\
\hline Aspiration pneumonia & 0 & + \\
\hline Tetanus & + & + \\
\hline Wound infections & + & ++ \\
\hline Psychological illness & + & + \\
\hline
\end{tabular}


by earthquakes (McCarty, 2002). However, unlike earthquakes, it is possible to detect tsunamis and cyclones in advance of these hazards, and provide early warning before they strike those vulnerable populations living along coastlines in their paths.

Preparedness is the aggregate of all measures and policies taken by humans before an event occurs that reduces the negative impact that otherwise would have been caused by the event (Sundnes and Birnbaum, 2003). Emergency health preparedness includes activities such as risk assessment, planning, hazard monitoring, early warning, and populationprotection measures. The objectives of preparedness for health emergencies have been offered as follows (Lechat, 1985):

- Prevent morbidity and mortality

- Provide care for casualties

- Manage adverse climatic and environmental conditions

- Ensure restoration of normal health

- Re-establish health services

- Protect staff

- Protect public health and medical assets

The actions required to meet these needs can be grouped in four categories (Lechat, 1985):

1. Preventive measures (e.g., building codes, floodplain management)

2. Protective measures (e.g., early warning, community education, evacuation, shelter)

3. Life-saving measures (e.g., rescue, relief)

4. Rehabilitation (e.g., resettlement, rebuilding)

Preventive and protective measures are not only the most cost-effective and efficacious actions that may be taken to protect human health from the hazards of cyclones and tsunamis, but they are also the most consistent with the promotion of human dignity and development. The tremendous societal impact of hurricane Mitch in Central America in 1998 dramatically illustrated the real costs of these natural disasters on development when the public-health accomplishments of an entire generation were wiped away by the storm (PAHO, 1998). The long-term impact on human health and development after the 2004 Indian Ocean tsunami is difficult to predict. It will likely take generations to restore the Aceh province (Indonesia) to pre-event levels, even with the assistance of nearly all of the richest nations on Earth. The world can no longer afford to sustain these significant losses in human development caused by these types of catastrophic natural disasters. Preparedness is the key to preserving human health in the wake of cyclone and tsunami disasters.

\section{DISCLAIMER}

The material in this article reflects solely the views of the author. It does not necessarily reflect the policies or recommendations of the Centers for Disease Control and Prevention or the U.S. Department of Health and Human Services.

\section{ACKNOWLEDGEMENTS}

The author would like to acknowledge the assistance and support of Dr. Jill Russell. This article is dedicated to my daughter, Cassidy. 四

\section{REFERENCES}

Alaska Division of Emergency Services. 1992. Tsunami! The Great Waves in Alaska. Alaska Division of

Emergency Services, Anchorage, AK.

Allworth, A. 2005. Tsunami lung: a necrotizing pneu- monia in survivors of the Asian tsunami. Medical Journal of Australia 182(7):364

Andresen, D., A. Donaldson, L. Choo, A. Knox, M. Klaassen, C. Ursic, L. Vonthethoff, S. Krilis, and P. Konecny. 2005. Multifocal cutaneous mucormycosis complicating polymicrobial wound infections in a tsunami survivor from Sri Lanka. Lancet 365:876-878.

Anonymous. 1997. Linking trees to tsunamis. Science 278(5340):1021, doi:10.1126/science.278.5340. $1021 b$.

Bissell, R.A. 1983. Delayed-impact infectious disease after a natural disaster. Journal of Emergency Medicine 1:59-66.

Bolt, B.A. 1978. Earthquakes: A Primer. WH Freeman, San Francisco, CA.

Boyarsky, I., and A. Shneiderman. 2002. Natural and hybrid disasters-Causes, effects and management. Topics in Emergency Medicine 24(3):1-25.

Brennan, R., and K. Rimba. 2005. Rapid health assessment in Aceh Jaya District, Indonesia, following the December 26 tsunami. Emergency Medicine Australasia 17:341-350.

Caldera, T., L. Palma, U. Penayo, and G. Kullgren. 2001. Psychological impact of the hurricane Mitch in Nicaragua in a one-year perspective. Social Psychiatry and Psychiatric Epidemiology 36:108-114.

Centers for Disease Control (CDC). 1986. Hurricanes and hospital emergency room visits-Mississippi, Rhode Island, Connecticut (Hurricanes Alicia and Gloria). Morbidity and Mortality Weekly Report 34:765-770.

CDC. 1989a. Deaths associated with Hurricane Hugo-Puerto Rico. Morbidity and Mortality Weekly Report 38(39):680-682.

CDC. 1989b. Update: Work-related electrocutions associated with Hurricane Hugo-Puerto Rico. Morbidity and Mortality Weekly Report 38(42):718-725.

CDC. 1993. Injuries and illnesses related to Hurricane Andrew-Louisiana, 1992. Morbidity and Mortality Weekly Report 42(13):242-3, 249-251.

CDC. 1996. Surveillance for Injuries and Illnesses and Rapid Health-Needs Assessment Following Hurricanes Marilyn and Opal, September-October 1995. Morbidity and Mortality Weekly Report 45(04):81-85.

CDC. 1999. Needs assessment following Hurricane Georges-Dominican Republic, 1998. Morbidity and Mortality Weekly Report 48(5):93-95.

CDC. 2000. Morbidity and mortality associated with Hurricane Floyd-North Carolina, September-October 1999. Morbidity and Mortality Weekly Report 49(17):369-372.

CDC. 2002. Tropical Storm Allison rapid needs assessment-Houston, Texas, June 2001. Morbidity and Mortality Weekly Report 51(17):365-369.

Chierakul, W., W. Winothai, C. Wattanawaitunechai, C.V. Wuthiekanun, T. Rugtaengan, J. Rattanalertnavee, P. Jitpratoom, W. Chaowagul, P. Singhasivanon, N.J. White, N.P. Day, and S.J. Peacock. 2005. Melioidosis in six tsunami survivors in southern Thailand. Clinical Infectious Diseases 41:982-90.

Chowdhury, A.M.R., Y. Chowdhury, A. Bhuiya, K. Islam, Z. Hussain, O. Rahman, R. Glass, and M. 
Bennish. Cyclone aftermath: Research and directions for the future. Pp. 101-133 in From Crisis to Development: Coping with Disasters in Bangladesh, H. Hossain, C.P. Dodge, and F.H. Abed, eds. University Press Ltd., Dhaka, Bangladesh.

Dalrymple, R.A., S.T. Grilli, and J.T. Kirby. 2006. Tsunamis and challenges for accurate modeling. Oceanography 19(1):142-151.

Diacon, D. 1992. Typhoon resistant housing in the Philippines: the Core Shelter Project. Disasters 16:266-271.

Fryer, G., P. Watts, and L. Pratson. 2003. Source of the great tsunami of 1946: A landlside in the upper Aleutian forearc. Marine Geology 204:201-218.

Goenjian, A.K., L. Molina, A.M. Steinberg, L.A. Fairbanks, M.L. Alvarez, H.A. Goenjian, and R.S. Pynoos. 2001. Posttraumatic stress and depressive reactions among Nicaraguan adolescents after Hurricane Mitch. American Journal of Psychiatry 158:788-794.

Guha-Sapir, D., and W. van Panhuis. 2005. The Andaman Nicobar Earthquake and Tsunami 2004: Impact on Diseases in Indonesia. Centre for Research on the Epidemiology of Disasters, Brussels, Belgium.

Guill, C.K., and W.X. Shandera. 2001. The effects of Hurricane Mitch on a community in northern Honduras. Prehospital and Disaster Medicine 16:124-129.

Holian, A., and P. Keith. 1998. Orthopedic surgery after Aitape tsunami. Medical Journal of Australia 169:606-609.

Hopkin, M. 2005. Indonesia spared tsunami as disaster quake strikes. Nature 434:549.

Insel, T. 2005. Coping with Hurricanes Katrina and Rita: Update from the Director. National Institute of Mental Health. [Online] Available at: http:// www.nimh.nih.gov/about/dirupdate_hurricanekatrina-coping.cfm [last accessed April 4, 2006].

Keenan, H.T., S.W. Marshall, M.A. Nocera, and D.K. Runyan. 2004. Increased incidence of inflicted traumatic brain injury in children after a natural disaster. American Journal of Preventive Medicine 26:189-193.

Kerr, R. 2005. Model shows islands muted tsunami after the latest Indonesian quake. Science 308:341.

Kongsaengdao, S. 2005. Treatment of Survivors after the tsunami. New England Journal of Medicine 25(352):2,654-2,655.

Krishnamoorthy, K., P. Jambulingam, R. Natajaran, A.N. Shriram, P.K. Das, and S.C. Sehgal. 2005. Altered environment and risk of malaria outbreak in South Andaman, Andaman and Nicobar islands, India affected by tsunami. Malaria Journal 4:32.

Krug, E.G., M. Kresnow, J.P. Peddicord, L.L. Dahlberg, K.E. Powell, A.E. Crosby, and J.L. Annest. 1998. Suicide after natural disasters. New England Journal of Medicine 338:373-378.

Lechat, M. 1985. Disaster as a Public Health Problem. Louvain University, Brussels.

Lee, L.E., V. Fonseca, K.M. Brett, J. Sanchez, R.C. Mullen, L.E. Quenemoen, S.L. Groseclose, and R.S. Hopkins. 1993. Active morbidity surveillance after Hurricane Andrew-Florida, 1992. Journal of the
American Medical Association 270:591-594.

Lim, J., D. Yoon, G. Jung, W.J. Kim, and H.-C. S. Lee. 2005. Medical needs of tsunami disaster refugee camps: Experience in southern Sri Lanka. Family Medicine 37(6):422-428.

Lim, P. 2005. Wound infections in tsunami survivors. ANNALS Academy of Medicine Singapore 34(9):582-585.

Malilay, J. 1997. Tropical cyclones. Pp. 207-227 in The Public Health Consequences of Disasters, E.K. Noji, ed. Oxford University Press, New York, NY.

Mason, J., and P. Cavalie. 1965. Malaria epidemic in Haiti following a hurricane. American Journal of Tropical Medicine and Hygiene 14:533-539.

McCarty, D. 2002. Tsunamis. Pp. 229-234 in Disaster Medicine, D. Hogan and J. Burstein J, eds. Lippincott William and Wilkins, Philadelphia, PA.

McMurty, G., P. Watts, G. Fryer, J.R. Smith, and F. Imamura. 2004. Giant landslides, mega-tsunamis and paleo-sea level in the Hawaiian islands. Marine Geology 203:219-233.

Meredith, J.T., and S. Bradley. 2002. Hurricanes. Pp. 179-186 in Disaster Medicine, D. Hogan and J. Burstein J, eds. Lippincott William and Wilkins, Philadelphia, PA.

Morgan, O. 2004. Infectious disease risk from dead bodies after natural disasters. Revista Panamericana de Salud Pública 15(5):307-312.

Moszynski, P. 2005. Disease threatens millions in wake of tsunami. British Medical Journal 330:59.

Mudur, G. 2005. Aid agencies ignored special needs of elderly people after tsunami. British Medical Journal 331:422.

Nicholls, R.J.N., N. Mimura, and J.C. Topping. 1995. Climate change in south and south-east Asia: Some implications for coastal areas. Journal of Global Environmental Engineering 1:137-154.

Noji, E.K. 1993. Analysis of medical needs during disasters caused by tropical cyclones: Anticipated injury patterns. Journal of Tropical Medicine and Hygiene 96:370-376.

Noji, E.K. 1997. Earthquakes. In: Public Health Consequences of Disasters, E. Noji, ed. Oxford University Press, New York, NY.

Norris, F.H. 2005. Psychosocial Consequences of Natural Disasters in Developing Countries: What Does Past Research Tell Us About the Potential Effects of the 2004 Tsunami? U.S. Department of Veterans Affairs, National Center for Post-Traumatic Stress Disorder, White River Junction, VT. [Online] Available at: http://www.ncptsd.org/facts/disasters/fs_ tsunami_research.html [last accessed April 4, 2006].

Oxfam. 2005. The Tsunami's Impact on Women. [Online] Available at: http://www.oxfam.org.uk/ what_we_do/issues/conflict_disasters/downloads/ bn_tsunami_women.pdf.

Pan American Health Organization (PAHO). 1998. Impact of Hurricane Mitch on Central America. Epidemiological Bulletin 19:1-14.

Paulson, T. 2005. New findings super size our tsunami threat. Seattle Post Intelligence, February 7, 2005. [Online] Available at: http://seattlepi.nwsource. com/local/211012_tsunamiscience07.html [last accessed April 4, 2006].
Perera, C. 2005. After the tsunami: Legal implications of mass burials of unidentified victims in Sri Lanka. Public Library of Science (PLoS) Medicine 2(6):e185.

Philen, R., D. Combs, L. Miller, L.M. Sanderson, R.G. Parrish, and R. Ing. 1992. Hurricane Hugo-related deaths: South Carolina and Puerto Rico, 1989. Disasters 16:53-59.

Satake, K., K. Wang, and B.F. Atwater. 2003. Fault slip and seismic moment of the 1700 Cascadia earthquake inferred from Japanese tsunami descriptions. Journal of Geophysical Research 108(B11): 2535, doi:10.1029/2003JB002521.

Sattler, D.N., A.J. Preston, C.F. Kaiser, V.E. Olivera, J. Valdez, and S. Schlueter. 2002. Hurricane Georges: A cross-national study examining preparedness, resource loss, and psychological distress in the U.S. Virgin Islands, Puerto Rico, Dominican Republic, and the United States. Journal of Trauma Stress 15:339-350

Scheffers, A., and D. Kelletat. 2003. Sedimentologic and geomorphologic tsunami imprints worldwide-A review. Earth-Science Reviews 63(1-2):83-92.

Schultz, J., J. Russell, and Z. Espinel. 2005. Epidemiology of Tropical Cyclones. Epidemiologic Reviews 27:21-35.

Sundnes, K., and M. Birnbaum, eds. 2003. Health disaster management: Guidelines for evaluation and research in Utstein style. Prehospital and Disaster Medicine 17(Suppl. 3):44.

Taylor, P., D. Emonson, and J. Schlimmer. 1998. Operation Shaddock-the Australian Defense Force response to the tsunami disaster in Papua New Guinea. Medical Journal of Australia 169:602-606.

Toole, M.J. 1997. Communicable disease and disease control. Pp. 79-100 in The Public Health Consequences of Disasters, E.K. Noji, ed. Oxford University Press, New York, NY.

United Nations Development Programme. 2004. Reducing Disaster Risk: A Challenge for Development. John S. Swift Company, New York, NY.

Ursano, R.J., C.S. Fullerton, and B.G. McCaughey. 1994. Trauma and disaster. Pp. 3-27 Individual and Community Responses to Trauma and Disaster: The Structure of Human Chaos, R.J. Ursano, B.G. McCaughey, and C.S. Fullerton, eds. University Press, Cambridge, United Kingdom.

U.S. Geological Survey. 2005. Earthquake lists. National Earthquake Information Center. [Online] Available at: http://neic.usgs.gov/neis/eqlists/eqsmosde.html [last accessed April 4, 2006].

Watcharong C., B. Chuckpaiwong, and B. Mahaisavariya. 2005. Orthopaedic trauma following tsunami: Experience from Phang Nga, Thailand. Journal of Orthopedic Surgery 13(1):1-2.

World Health Organization (WHO). 1979. The risk of disease outbreaks after natural disasters. World Health Organization Chronicle 33:214-216.

WHO. 1992. Psychosocial Consequences of Disasters: Prevention and Management. WHO/MNH/ PSF/91.3. World Health Organization, Geneva, Switzerland.

Williams, J. 1997. The Weather Book. 2nd ed. Vintage Books, New York, NY. 